\title{
THE ROLE OF RED STAR FOOTBALL CLUB IN THE CONSTRUCTION OF SERBIAN NATIONAL IDENTITY
}

\section{IVAN ĐORĐEVIĆ}

The main aim of this paper is to provide an analysis of social, political and historical processes, in which due to very specific circumstances Red Star Belgrade FC became the Club - Hero. As such, it inherits diverse "values", marking the team as a real national symbol.

Keywords: Red Star Belgrade FC, football, nationalism, former Yugoslavia, Serbia
$V$ prispevku avtor analizira socialne, politične in zgodovinske procese, v katerih je zaradi specifičnih okolišcin beograjski nogometni klub Crvena zvezda zaslovel kot „klub-heroj«. Vtem klubu so se gojile in ohranile različne "vrednote", zaradi katerih se je nogometna ekipa dejansko vzpostavila kot nacionalni simbol.

Ključne besede: nogometni klub Crvena zvezda, nogomet, nacionalizem, nekdanja Jugoslavija, Srbija

"It was the hand of God, the stadium exploded", is the memorable quote of the commentator during the live broadcast of European Champion Clubs' Cup semi-final match, between Red Star FC and Bayern Munich, when Red Star scored the equalizer, leading it to the final round of the competition. On that spring night in 1991, this Serbian club wrote the most glorious pages of Yugoslav football history. Meanwhile, the country this club represented, Yugoslavia, started the final episode of process which in the coming years ended in final dissolution of the state and bloody civil war that accompanied it.

Today, 25 years later, Red Star is far remote from its former glory. Financial problems caused by war combats and the later process of transition, accounted for low quality football being played at the stadium Marakana in Belgrade. The epic encounters with AC Milan or Bayern Munich became folklore tales told by older club sympathizers, while in reality Red Star is being defeated by lower league teams in the qualifying rounds of European competitions. The position of far periphery of modern football game, in which the Serbian club currently exists, is contemporary faith of many Eastern European teams. Despite this semi-depressing situation, the Marakana stadium in Belgrade is still full, and the club's fans still firmly believe in the slogan- "Red Star is life, everything else are trifles". However, in the past couple of years, any casual visitor surely noticed that the stadium was scenery for more than just supporting of the beloved team. Slogans such are "Kosovo is the heart of Serbia", "Kill a Croat, so Albanian loses a brother", or "Kill the faggot" are the dominant sang repertoire of the most passionate fans. The latter creates the impression of the club's supporters being a political organization rather than a fan group (Čolović 2014). This type of political engagement by a fan subculture

* This paper is a result of research conducted within the project "Cultural Heritage and Identity" (No.177026), fully financed by the Ministry of Education, Science and Technological Development of the Republic of Serbia. 
marks the supporting of one's team as more than a matter of football. It becomes a matter of a broader view, in which Red Star is seen as „more than a team“. It is perceived as a carrier of symbolic values which go far beyond the game. These values mostly refer to the question of national identity, with Red Star embodying all the preferred attributes of the nation.

The main aim of this paper is to provide an analysis of social, political and historical processes, in which, due to very specific circumstances, Red Star became the Club - Hero. As such, it inherits diverse „values“, marking the team as a national symbol par excellence. By combining different sources, I aim to point out how a football team transformed from a local to a national „brand“, with a special attention given to the role football played in the process of dissolution of Yugoslavia. In the first segment of the paper, the history of Red Star, from its beginnings in 1945 until the 1980s is laid, with an emphasis on the rival relations the club had with the other relevant Belgrade-based team- Partizan FC. Further, I concentrate on the processes, leading to the increase of nationalism at football fields, as connected to nationalization of the political space of Yugoslavia and Serbia during the 1980s. Following the development of the above stated processes, in the main segment of this paper I focus on the impetus of Red Star's transformation to the "pillar of Serbdom“, assuming this role from the national team of "rump” Yugoslavia, consisting only of Serbia and Montenegro. The status of national heroes adopted by Red Star fans also implies their importance in the later political processes; such is their role in subversion of the regime of Slobodan Milošević on the October 5th, 2000. Later process of transition, despite the continual decay in the football domain, did not decrease the political legitimacy neither of football fans, nor of Red Star, as a football club. Their role of "patriotic watch-dogs" was not diminished in time, despite the tendencies towards democratization and liberalization of Serbian society. In the current social momentum, when the process of Serbian transition into a capitalist economy on Europe's periphery is rounding, the interest in the "national question“" is almost abolished, especially when compared to the 1990s period. Having the latter in mind, in the concluding segment of the paper I discuss the positioning of Red Star as ,inherited“ national symbol in the times that „do not demand heroes“.

\section{FOOTBALL IN THE NEW AFTER-WWII YUGOSLAVIA}

The football club Red Star was founded in March 1945, few months following the liberation of Belgrade after German occupation during WWII. The club was established within an initiative of members of United Federation of Anti-Fascist Youth of Yugoslavia, one of the bodies arising from victorious partisan army under the leadership of Josip Broz Tito ${ }^{1}$. Almost simultaneously, in October 1945, the other major football club, Partizan FC, was established by Yugoslav Army in Belgrade, following the model used by Soviet sports.

1 The official history of FC Red Star, available at http://www.crvenazvezdafk.com/sr/istorija.html, accessed on 15 December 2015. 
These two clubs, alongside Croatian teams Dinamo Zagreb and Hajduk Split, formed the future "grand four" of Yugoslav football. The four won almost all trophies in the period from the ending of WWII until the dissolution of Yugoslavia, in the beginning of 1990s.

Even though powerful and successful football clubs existed in the pre-WWII period, such were BSK and Yugoslavia, their activities were banned by the new communist authorities, due to their somewhat problematic role during the German occupation (Zec 2010, Andjelić 2014). Namely, the local government, supported by German military authorities, organized several competitions in which the named clubs took part in the period between 1941 and 1944 (Zec 2011). The stated activities were characterized by the new government as collaboration with the occupation forces, with their abrogation as logical consequence. Therefore, founding of Red Star and Partizan represented instigation of radical discontinuity with the previous state. Both clubs in that sense were new sporting institutions, supported both organizationally and financially by the new government. While being a state project, both Red Star and Partizan headed sports' domain in the coming after-war decades, consequentially formulating a large fan base.

From this viewpoint, it is possible to state that the organizational models of these two Belgrade-based clubs didn't differ much from the other East-European football collectives. Following the example of Soviet clubs, they all had powerful patrons in institutions such are military, police or an important state owned corporation (Riordan 1999: 48-49). Having in mind the close link to state power one aim, set for the public activities of sport institutions, was to promote the state system of socialist Yugoslavia.

On the other hand, this type of organization opened substantial room for subversion, even though very strictly controlled by its patrons, i.e. the powerful institutions of the state. In this sense, football was one of the points in which a citizen could demonstrate his/hers free choice, by choosing the team to support (Edelman 2013: 143-144). At this point, it is interesting to refer to thoughts of Soviet anthropologist Levon Abrahamyan, given in conversation with a journalist in early 1990s, in Moscow: „In a communist country (...) the football club you support is the community you yourself choose to belong to. The regime did not send you to support a club, and with the exception of the Western ones, you could freely choose your team. This was maybe the only opportunity for an individual to choose its own community, and within it, to freely express himself / herself. (...) being a fan (...) meant to gather with others and be free“2 (Kuper 2007: 56).

A comparison can be made with Yugoslav and Serbian football in the period after WWII. The choice made between the two most popular Serbian and Belgrade clubs, Red Star FC and Partizan FC, was perceived as a matter of cultural preference bound with expressing of a political stand, and with demonstration of social background of an individual. Partizan

2 This is a translation of Serbian edition of the book "Football Against the Enemy" by Simon Kuper and it is made by the author of this paper. The original, English edition of the book was not available to the author at the moment of writing this paper. 
FC, as a military sports club, was largely perceived as a state project and a as a part of the state's system until the 1970s. It was perceived as a club supported only by „soldiers“ and „newcomers“. On the other hand, Red Star FC was perceived as a „true Belgrade team“ (Žikić 2012: 109), to some extent seen as anti-regime, if nothing, then for being perceived as a "Serbian“, and not as an „Yugoslav“ club like Partizan FC.

Regardless the fact that both Red Star and Partizan were official system's clubs, equally supported and financed by the state structures, the dichotomy between the notion of „Serbian“ and „Yugoslav" nested in the two Belgrade-based clubs, was widely present on the cognitive map of Yugoslavia. The majority of Serbian population who lived in other Yugoslav republics dominantly supported Red Star FC as their club of choice, interpreting this aligning as one segment of their national identity.

This informal interpretation of club's history was, however, created within the circles of Serbian intellectual elite. Then formulated narrative of „Serbian“ and ,anticommunist“ character of this Belgrade club, gradually became the „true history“.3 Even though, no public anti-communist action, either by the club's leadership, or by its supporters, was made before the end of 1980s, the potency of the created narrative remained strong until this day.

The formulated perception had a significant impact on later events occurring during the 1980s, when Red Star FC was endowed with the epithet of „pillar of Serbdom“, while its supporters were considered for „patriotic avant-garde“ of the time. The mythologizing of the club, established, as already stated, by the United Federation of Anti-Fascist Youth of Yugoslavia, in 1945, went so far, that the contemporary perception of the first fan group is the one of "thugs or bohemians, Young Belgraders, which did not like the army or the crumbling communist system" (Wilson: 107). The club is described with following words: "We all know that the notion of Serbdom is inextricably bound both with Red Star FC and with its supporters, from the first sympathizers to the organized fan groups“. 4

\section{RED STAR- SERBIAN STAR}

During the 1980s, in the aftermath of Josip Broz Tito's death, a significant change of political climate came to forefront within Yugoslavia's territory. The rise of nationalist ideology on

3 This narrative, present in the informal circles of Serbian cultural elite during the 1960s and 1970s, was formulated by very influential journalist and writer Bogdan Tirnanić. In his book, "Belgrade for beginners" ("Beograd za početnike"), published in 1983, Tirnanić described Red Star fans as authentic rebels, who were against every kind of authority and the Communist Party in particular. According to him, people who supported Red Star were bearers of the authentic Belgrade and Serbian spirit, seeing their club as a symbol of subversion. Tirnanić's description summed up narratives already present among famous national writers, artists and journalists. These were later on used as a proof of "true" Serbian character of Red Star by nationalistic elites.

4 Offical web page of Red Star's fan group „Delije“ http://www.oaza.rs/sport/delije/index.php , accessed on 24 December 2013. 
the highest levels of Communist parties of member states, gradually liberated from centralized authority, transgressed to the stadium-based events. Young football fans, "freed from constraints" of still alive communist ideology, turned towards interethnic confrontations, therefore becoming, in certain way, the avant-garde of "nationalistic explosion", culminating in a civil war in several years. By that time forbidden offensive songs and slogans slowly became a part of fan folklore. Earlier tensions between the fan groups of the "great four" were less football-based and increasingly ethnically motivated (Čolović 2000: 338-342, Lalić 1990: 124-129). Stadium stands in Serbia and Croatia became spaces for promotion of new nationalist leaders, and the supporters of Red Star FC had one of the major roles in this process. The new nationalistic elites in constituting republics of Yugoslavia have embraced the ethnic-based violence with opened arms, in that way gaining a new and unexpected ally in achieving their goals, which lead to the dismantlement of Yugoslavia.

Even though the nationalistic folklore was present at almost all stadiums in Yugoslavia, two events had a core impact on transformation of Red Star FC from being just one of the two Belgrade clubs to the symbol of the "Serbian nation“ as a whole.

The first event, today well known violent clashes between the fans of Dinamo Zagreb and Red Star FC at the „Maksimir“ stadium (Nielsen 2010: 89-90, Mills: 1200-1201, Mihailović 1997, Sack and Suster 2000, Andjelić 2014), took place in Zagreb, Croatia’s capital, in 1990. The ethnic-based riots, occurring in the eve of the never-played game between the two teams, instigated a storm of mutual accusations in both Serbian and Croatian public. The symbolic potency of this game, named „one of the football games that changed the world" by CNN (CNN, January 13, 2011), turned it into a metaphor for the beginning of the war. It is used as such even two decades later, through the phrase „the war started at Maksimir" (Đorđević 2012).

The described clash would cause neither this scope of reaction nor the following political instrumentalization, if its main actors, the football fans, were not already a relevant political factor in Yugoslavia. In order to understand the specificity of the relation between football fans within the territory of socialist Yugoslavia and later war events, it is necessary to emphasize that the football vandalism was used as „pre-military training" (Čolović 2000: 348), as it was colorfully described by Ivan Čolović. Namely, after the beginning of the armed conflict in Croatia, and later in Bosnia and Herzegovina, in the early 1990s, one of the main basis for military recruiting was among the football fans, especially among the fans od Red Star FC, „Delije“.

5 The situation was similar in Croatia, where a large number of members of Dinamo Zagreb's and Hajduk Split's fans joined volunteered units of then forming Croatian army. While this paper deals specifically with Red Star FC, I will not elaborate in detail the specificity of other Yugoslav clubs. More on this issue can be found in Đorđević 2015a.

6 Ražnatović, was a criminal well-known for his activities in Western Europe during the 1980s and for his cooperation with The State Security Service. To the public he was known as a leader of Red Star fans at the end of the 1980s. He is credited for unifying the divided fans under one single group, 
Volunteer Guard was formed, with its basis formed by the members of „Delije“ (Čolović 2000, Vrcan and Lalić 1999). Ražnatović later explained that he decided to organize a paramilitary formation immediately after the events at „Maksimir“ stadium, claiming that he predicted the beginning of the war (Čolović 2000: 344). Even though, not much is known about his activities at „North"7, it is undeniable that in the summer of 1990, Arkan had a very significant role in the functioning of Red Star fans. It was speculated that he was infiltrated by the State Security Service with a task of politically pacifying the fans. Therefore, they were diverted from the daily-political events towards the broader, more important goal - „the defense of Serbdom“. ${ }^{8}$ Many authors later dealing with this topic (Foer 2004, Wilson 2006, Nielsen 2010, Mills 2009, Vrcan 2003) emphasize Arakan's role and the role of football fans in the war combats in Croatia and Bosnia in the early 1990s. In these respect, Foer states „that the Red Star fans would become Milosevic's shock troops, the most active agents of ethnic cleansing, highly efficient practitioners of genocide" (Foer 2004: 13).

Football fans in former Yugoslavia were indeed recruited for the war, in that way leaving the domain of ritual war and entering the real one, where "the aggressiveness of the fans becomes a precious 'capital of hate', and a fan very-welcomed canon flesh “ (Čolović 2009). The latter largely defined the future and the position of the fan groups in both Serbia and Croatia, allowing them political legitimacy not many other fan groups in Europe ever gained. Among them, the Red Star's „Delije“ were the forerunners of the „fans-patriots“.

The second event, that launched Red Star FC directly to the orbit of "nationalstardom", was winning of the European Champion Clubs' Cup, the most important European club championship in 1991. In the autumn of 1990, the club from Belgrade started a campaign in which the football giants such are Glasgow Rangers, Bayern Munich, and, finally, Olympic Marseille, were defeated. This triumph marked the greatest success of Yugoslav club football in history. The winning team of Red Star FC was indeed Yugoslav in a true sense. It consisted of the best football players from Macedonia, Montenegro, Croatia, Bosnia and Herzegovina and Serbia, therefore presenting the ethnic structure of the former state. However, even if the team that battled the European giants was Yugoslav in its ethnic diversity, Red Star FC was a primarily Serbian club on a symbolic scale. On the

"Delije". As a leader of later formed Serb Volunteer Guard, he was indicted by the International Court for War Crimes in Den Hague. He didn't live to the beginning of the trial, while he was killed in shooting, in 2000.

7 „North” refers to north stand of Red Star's stadium „Marakana“, a place where the most dedicated fans gather.

8 Documentary serial „40 years of cheering in Serbia. Dossier football fans“, episode 3, available at http:// www.youtube.com/watch? $v=$ R04llbN2p4I\&list=PL8EFAA320F48CE800, accessed on 12.12.2015. In this episode one of the Red Star fan group leader offered a testimony over a meeting with Arkan, in 1990. On this occasion, the "Commandant", as the interviewee refers to Arkan, elaborated on his vision in which a clear accent is placed on the readiness of fans to transform their patriotic feelings into real action, within the battle for Serbian interests in the coming war. 
stands, nationalist songs were largely present and the name of the state, if ever chanted, was Serbia. According to the general mood at the finals in the Italian city of Bari, in the halftime the Red Star fans displayed a colossal Serbia flag with nineteenth century symbols, at their stand. This act was saluted with fervor in Serbian public, and even today "Delije" emphasize it as the pinnacle of rooting for their club at the finals in Bari. As Richard Mills noted, displaying of this symbol of Serbian nation probably meant little for the European viewers, who could hardly understand the play of symbols at the stadium stands in Bari. Mills references the words of one of his interviewee: "At that time it didn't matter to the fans, they supported only one state in that time, at that moment, that state was Red Star. No Yugoslavia, no Serbia, nothing - they supported only Red Star" (Mills 2009: 1198). However, he rightly emphasizes that the displayed flag was Serbian, and not any other, and that exactly this act was a direct message to the rest of Yugoslavia that the success of Red Star FC is the success of Serbia and not of the joint state (Mills 2009: 1198). Furthermore, the celebration of the European title, won by the Belgrade team, outside of Serbian territory did not imply a mass participation of other Yugoslav ethnic groups; it rather implied that the majority of Serbs outside of Serbia's borders supported Red Star FC.

Even if there were "only eleven presidents on the field" (ibid: 1198) for the fans, media has long time painted a different picture. Namely, the achievements of Red Star FC became an integral segment of the dominant discourse of Serbian nationalism. Along this line, writer Petar Džadžić stated: „During the 1970s my friends and I selected four representative institutions in the contemporary social life of Serbs: Serbian Academy of Science and Arts, daily 'Politika', publisher 'Prosveta' and Red Star FC“ (Politika, 30.1.1989; Čolović 2000). Similarly, writer Brana Crnčević stressed out in an interview for the magazine Sport that he is a Partizan FC fan but he also supports Red Star FC. He explained this paradox with a fact that the achievements of this club were of a significant relevance for both Serbs in diaspora and for Serbs living here (Sport, 26.12.1991; Čolović 2000). Furthermore, in an article titled „Red Star - Serbian Star“, published following the victory of Red Star FC in Bari, the most infamous daily in Serbia - 'Politika' - emphasized that this sporting success was of an outermost importance for Yugoslavia, but primarily for Serbia (Mills 2009: 1199).

The provided examples indicate the complexity of relations between football and broader social and political surroundings in Serbia and Yugoslavia in the period of late 1980s and early 1990s. The Red Star fans supported by nationalistic political elites in Serbia had an important task to demonstrate in a large arena, in a live broadcast, what is the real vox populi. Symbols, such were the colossal Serbian flag displayed on the stands in Bari, singing of nationalistic songs and chanting to Serbia, were, in the end, the only message sent to the public. In the time of dominant nationalist discourse, the exploitation of these memorable momentums in media left little room for any differing interpretations. Gradually, football in Serbia was permanently colonized by politics. Both due to its immense success, and due to political and military engagement of its fans, Red Star FC was assigned the role of a Club - Hero and of a „pillar of Serbdom“. It was designated as symbol 
that unconditionally gathers, and on a discursive level unifies the „immanently divided” nation. It is in this way, that „Delije“ gained a significant political capital and legitimacy embodied in unquestionable patriotic aura after the dissolution of Yugoslavia. This is the key for understanding the interrelation between football and nationalism, which has been present in Serbia since the 1990s until this day.

\section{RED STAR, SERBIA, NEVER YUGOSLAVIA}

Football in the „rump” Yugoslavia, a state composed of Serbia and Montenegro following the dissolution of SFRY, was very quickly affected by the UN sanctions, instated due to the states involvement in war combats in Bosnia and Croatia, in May 1992. Severe economic crisis and war surroundings caused a sudden devastation of football, leading to the disintegration of the champion team of Red Star FC. Additionally, leaving of "prominent fans” to war caused a decline of visitor numbers at the stadiums. The turbulent years placed football in the background. In the aftermath of armed conflict in Bosnia and Herzegovina, in the mid-1990s, it became clear that the "honeymoon" phase of the relations between „Delije“ and Serbian president Slobodan Milošević was over. The political instrumentalization of football fans of the late 1980s and early 1990s has fulfilled its purpose with the dissolution of Yugoslavia. When their task as representatives of "national avant-garde" and as volunteers in diverse military and often paramilitary formations was fulfilled, a need for their engagement suddenly disappeared. Serbian government at that point led an extremely ambivalent "national politics". While firmly assuming a stand that "Serbia is not at war", the regime meandered between clearly nationalistic positions of "defense and protection" of rebelled Serbs in Bosnia and Croatia, and denying of any involvement in the conflicts occurring in the neighboring countries. The West-European countries and USA perceived Milošević as a "Balkan butcher" at times, while in the next moment he was seen as a "strategic partner", or the "guarantee of peace and stability in Balkans". The latter dichotomy was the main cause for appearance of a clearly negative relation of the football fans towards Miloševićs regime, as early as in mid-19 90s. It can be said that if the nationalism promoted by his regime, only few years earlier, could count on the support of the football fans, Miloševićs "betrayal" of Serbs in Croatia and Bosnia, as his actions were perceived in the "patriotic" public, turned the fans against the regime.

At this time, the ambivalence of Serbian authorities towards the so called "national question "was mirrored in one more important issue. Despite an unquestionably nationalistic politics, the regime never took a clear stand on the issue of „national identity“. Essentially, „Miloševičs regime firmly relied on the rhetoric of continuity with socialism and Yugoslav notions of tolerance and multiculturalism, therefore playing with and managing simultaneously both the pro-Yugoslav and nationalistic sentiments of Serbian citizens" (Vasiljević 2011: 67, Jansen 2005: 20-24). Milošević and other representatives of the regime have 
rarely offered clear stands on the so called „national interest“, with this task delegated to the regime-loyal media. Therefore the official stand of the regime towards these issues remained permanently blurry and easily subjected to changes and manipulations, of sometimes colossal proportions, with the above mentioned position on the Serbs in Bosnia and Croatia, as an example (Tompson 2000, Đerić 2007, 2008b, Vasiljević 2008). Keeping of the former Yugoslav anthem „Hej Sloveni” [„Hey Slavs“] as the official anthem of the new state, is a very good illustration of this politics.

The official relation towards the anthem was more or less ambivalent in the times following the dissolution of SFRY (Spasić 2003: 112). Many people held nostalgic feeling towards it, as a reminder of „calmer and happier“ times of Tito's Yugoslavia, through a „passive nostalgia“ as defined by Mitja Velikonja (Velikonja 2009:376). At the same time a significant number of people understood this anthem as a relic of communist Yugoslavia, with which one should finally and forever part from. The fans od Red Star FC clearly articulated this stand with a slogan, often heard at the stadium: „Zvezda, Srbija, nikad Jugoslavija“ [„Red Star, Serbia, Never Yugoslavia“]. „Delije” went even further in taking an official stand not to support the national football team, as long as the state is called Yugoslavia, and as long as the symbols of the old state are used ${ }^{9}$. This „war of symbols” resulted in mass booing and loud disapproving during the intonation of the anthem at the stadiums. However, in time, this type of protest against the ancien régime, became a powerful tool in the insurgency against the regime of Slobodan Milošević. The booing of state's anthem was no longer only a way of expressing „national emotions“, it became an efficient method of symbolic battle with the regime, which was as anachronous as well as its symbols. Such manifestation of dissatisfaction greatly impacted the support given to the national team. The football fans had a truly ambivalent relation towards it, as a symbol of the state they don't essentially accept.

Sticking of the state between the "communist inheritance" and open nationalism caused the inability of the national football team to fully assume the capacities for mobilizing collective identity, as it was the case in Croatia, for example. The "nation building" project was in this sense left unfinished. However, the "nationalized" political space (Brubaker 1996) could not exist without such a symbol. Therefore, this space was inhabited by the football club Red Star FC, both because of the previously constructed narrative, and because of the continuity it established on the positions defined as "Serbdom“.

This political and „patriotic“ capital of the Red Star fans wasn't only symbolic in its character, rather it had an impact in the domain of real political struggle, now against the former ally Milošević. As soon as 1996, on the occasion of the mass protests in Serbia „Delije“ joined, though unofficially, the protesters demanding recognition of the local government elections. In most municipalities in Serbia these elections were won by the leaders of the opposition, and it was this fact that the regime wanted to avoid recognizing. One of the most

9 According to http://www.oaza.rs/sport/delije/prica 
famous slogans shouted in the streets at this time was ,'Ajmo,'ajde, svi u napad" ["Let, Let's all strike"], actually a fans' song, widely sang on the North stand of the Red Star FC's stadium. With the outbreak of Kosovo crisis in 1998 and the NATO intervention in the spring of 1999, football and happenings connected to it again fell to the background. However, the events which followed brought the football stadiums to the spot-light of political developments once again. While the demonstrations in 1996 were a non-violent protest against regime, the uprising in 2000 had an utterly different character. The repression imposed by Miloševićs regime, starting from murdering and arrests of political opponents, to violent suppressions of any form of rebel, brought the football fans back to the grand stage. They represented the physical strength, until then largely missing within the ranks of the political opposition, needed in order to truly stand against aggressive state apparatus. From one side, the football fans were perceived as patriots, therefore giving legitimacy to the opposition often faced with accusations of "treachery" or of being "foreign bribed and paid". At the same time, inclination towards violence, which in other circumstances might be unacceptable, in the named political moment was seen as more than welcomed by the opposition parties, as a "punching fist" in the clashes with the aggressive regime. At that moment the football fans were the only group willing and ready to enter a physical confrontation with the police.

The crucial shift in the relation between the regime and football fans was clearly seen on July 27th 2000, at the Champions League qualification match at the stadium of Red Star FC, where the home team encountered FC Torpedo Kutaisi from Georgia. On that day, a huge clash occurred between the police and the Red Star fans, after the police raided a segment of the Northern stand, as a reaction to the fist-time sang „Spasi Srbiju i ubij se, Slobodane" [, Save Serbia and kill yourself, Slobodan"] slogan. These riots at the stadium marked a beginning of an open war between Red Star fans and Miloševičs regime, and the mentioned slogan became an unofficial anthem of the protests led by the opposition parties.

Football fans of different clubs were important participants in the events occurring on the October 5th 2000, when after multiday protests against regime's attempt to steal the state elections, a mass protest meeting was organized in Belgrade. The protest turned into violent clashes between the citizens and the police. It resulted in Miloševićs's recognition of election results and the victory of the opposition's candidate for the president of Serbia, Vojislav Koštunica. The stories of football fans fighting on „the first lines of fire” quickly reached a mythological status. Only two months after the change of government, the leading opposition media - Radio B92 - awarded the Red Star fans for their contribution to „revolution“, declaring them „heroes of democracy“, at a formal ceremony at the cultural center Rex in Belgrade. On that occasion they gave the following elaboration: „These boys, who for ten years stood up against the regime, and clashed with the police while others were safely sleeping in their homes. They are 'Delije'. ${ }^{10}$

10 According to: http://www.nspm.rs/komentar-dana/licemerje-i-neprofesionalnost-medija-druge-srbije. html?alphabet=1 
In this way, the political capital given to the Red Star fans in the period from of Yugoslavia dissolution was revalorized and reinforced. This time they were not perceived by the public as the patriotic heroes, but as heroes of democratic revolution. However, there was very little change in their core nature and character during this decade. Namely, in the fan imagination, Milošević was not a problem because he led the nation into a war, but rather because he lost that war. This was the main reason for "Delije“s uprising against the political regime, and the later recognition of their role in the anti-regime fight reinforced their political influence and the position as an institution embodying the "true" national and patriotic values.

\section{BEING A RED STAR FAN IS TO BE A SERB}

Despite the great expectations, the fall of Miloševićs regime and democratization of the country didn't bring any improvement in the domain of football. Indeed, the bareness of transition model from state socialism to capitalism manifested itself clearly in the matters of football. Similarly to other East European countries, Serbian football suffered from a permanent lack of qualified staff, from inclination towards corruption and from close connection to organized crime (Goldblatt 2008, 685). The former glory of clubs such are Red Star FC and Partizan FC was never regained, while non-transparent management and sales of young players became the only models of functioning of these once strong sport collectives.

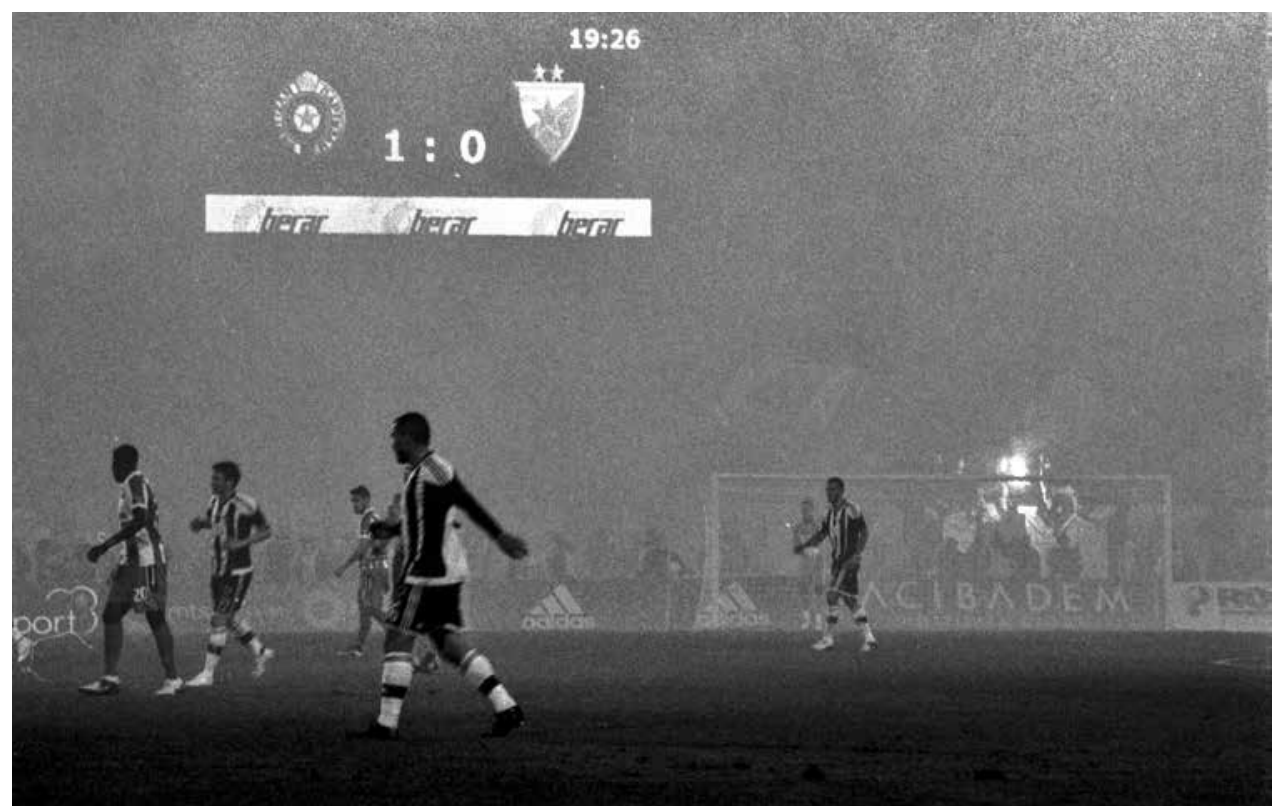

The Belgrade derby between Red Star and Partizan Belgrade. Belgrade, The Partizan Stadium. February 27 2016. Photo: Valentino Bianchi. 
The expectations of the new democratic government that the problems in football will resolve on their own only by the act of subverting Milošević with football fans as allies along the process, proved to be a bad estimation. Only ten days following the political changes of October $5^{\text {th }}$, huge riots occurred at the game between Red Star FC and Partizan FC, setting the trend for hooliganism that will escalate more and more in the first decade of $21^{\text {st }}$ century. An attempted murder of a police officer on the North stand of Red Star's stadium in 2007 is only one example of this extreme practice. This case is an exceptionally interesting example, not only because of the extremely violent crime fan Uroš Mišić was accused for, but because of the long lasting and extensive campaign, titled "Justice for Uroš", led by the Red Star fans. The campaign was present in public for years with a goal of applying pressure to the justice system to free the member of their fan group. The pressure and public attention given to this event points to the relevance of "Delije" as a social factor in Serbia. If it had occurred anywhere else except at the stadium, this ruthless attack on a police officer would be legally processed without much media coverage. However, when it came to the football fans, the authorities were not ready to take a clear stand towards such a violent act. Even though the fan in question was finally sentenced to prison time, it was clear that his case was special.

Essentially, this example points that the Red Star fans have left the domain of a subculture and became a composite part of the „main-stream“ politics between the late 1980s and early 1990s. That is how „Delije“, as an example, have transformed to patriotic heroes, and then later the punching fist in the battle against Miloševićs regime. Political elites in Serbia have willingly accepted an essentially violent subculture - such fans are - in the regular political streams in the times of deep social crisis. However, when the more peaceful times rolled in, the political capital of the fans became an uncomfortable burden. That is why today the clashes between the fans of Red Star FC and Partizan FC are publicly referred to as hooliganism. Furthermore, having in mind that the fan groups are operating as they were taught, substantial rise of confusion among their lines is appearing. They, as well, are puzzled how it is possible for patriots and heroes to become a threat overnight. And how come the attack on Miloševićs police in 2000 is considered to be a heroic deed, when the basically same act few years later is treated as a serious crime? The given example of the campaign "Justice for Uroš", demonstrated the consequences of made synergy between the political domain and a violent subculture.

Based on the stated synergy and the political capital gained through it, the Red Star fans became the moral arbitrary when it comes to the questions of "national interest" in the 21st century. Approaching the EU and liberalization of Serbian society, as the proclaimed aims of the new government, did not align with the vision of the football fans, when it came to the future of Serbia. In that sense, the public support to Ratko Mladić and Radovan Karadžić, indicted for war crimes, and allegation for betrayal of Kosovo, became a custom background of football games. Maybe the most effective illustration of fans' political stand is the banner made and displayed by the fans of Red Star FC, in August 2014: „Zapad nemo gleda šta Šiptari rade, važno je da ovde hoće gej parade! Ljude nam ubijaju crkve 
naše pale, zato nas u Briselu na sva usta hvale! Hvala Evropo mi možemo bez tebe, u savez sa Rusima, a druge ko jebe!“ [”, The West silently watches what Albanians are doing, it is more important to have the gay pride! Killing our people and burning our temples, that is why in Brussels they like us! Thank you Europe, we can do without you, in alignment with Russians, and who fucks the rest"].

In these sentences the entire worldview of "Delije" is nested. The enemies are, namely, the West, the EU, Albanians and the LGBT community, while the desired society is embodied in Serbian Orthodox beliefs and traditions, and in the alignment with Russia. Such political agenda can't be considered as exceptional for a fan subculture. As Christian Nielsen notes, the link between extremism and football hooliganism, that very often fits within the positions of extreme right-wing politics all over Europe, is not a specificity of the fan tribes in Yugoslavia (Nielsen 2013: 1-2). However, what distinguishes the fans of Red Star FC from their "peers" in other countries, is the fact that at one point political elites gave their support and encouragement to transformation of ritual transgression into actual violence, occurring within the territory of former Yugoslavia.

When the ritual fan violence once moves to a real-political field, it is very hard to instigate a reverse process. The relation of „Delije” towards one of their enemies stated in above mentioned transparent, the LGBT community, is maybe the best example of the previous conclusion. In these terms the attempts to organize the „Pride parade” is a good illustration. Numerous attempts were made throughout several years to hold the „Pride parade” in Belgrade. These efforts usually failed due to the „security reasons“. Even if the parade was held, it had a format of a highly protected gathering of people, separated from their violent opponents by the police. The „security risk“ discussed here, in its core is an euphemism for the extreme far-right political organizations, from which the majority inclined to fan groups (Mikus 2011, Nielsen 2013, Đorđević 2015b). During the past years, these groups succeeded by threat of violence to prevent the „Pride parade” from being held. On the occasion of „Pride parade” in 2010 a mass clash with the police took place in the streets of Belgrade. Even though opposing, voiced by organizations of extreme right political agenda, to this type of a manifestation can be expected, the manner of expressing that view in this case points to something else. It points to the unwillingness of the state, in normal circumstances, to control one relatively small social group. However, the Red Star fans are not a relatively marginal subcultural group, but rather, if necessary, can become an efficient paramilitary formation, due to their deep connections with the political domain and with a deed on patriotism. The violence occurring during the „Pride parade”, testifies to the still existent political credibility of „Delije“, which can be newly instrumentalized if necessary for the purposes far beyond football.

Words of Vladan Lukić, the former club's president, in addressing the fans in 2010 testify to still present "patriotic aura" of Red Star FC in the official narratives. He stated: "When all was going well for Red Star, all was going well for Serbia as well. Red Star is the greatest sport brand of Serbia, by which we are recognized in the world. Being a Red Star 
fan - is to be a Serb. They have tried to destroy us, to impose Yugoslav clubs as a Serbian brand. They did not succeed, because of the millions of Red Star fans. They did not succeed, because blow to Red Star means a blow to Serbia. And we all know what happened to those who attempted to attack Serbia in the past!" (Blic, 4.5.2010).

Football club Red Star has crossed a long road from its creation until this day. It was a club that enjoyed all the privileges within the system of socialist sport. Its fans defined themselves as "true" Belgraders in the local identity play, unlike those „newcomers", "regime" fans of their rival Partizan FC. This identity narrative, framed by some members of cultural elite, took roots and gradually transformed into a story if the ,anticommunist” character of Red Star FC. The increasing nationalism of the 1980s proved to be a fertile soil for "formalizing" this parallel history, so Red Star became the Club-Hero and one of the „pillars of Serbdom" in the pervasive quest for national symbols. Symbolic potency arising from this created narrative, alongside with the gained patriotic capital of the 1990s, led to forgetting of the official club's history. The red star, the symbol of the victorious partisan army during WWII, became a synonym for Serbian nationalism. The political credibility of the club's fans, which came from this symbolism, still today presents a real power in Serbian society. However, the "patriotic agenda" in the contemporary Serbia under the economic burden of life on Europe's periphery certainly is not as actual as it was during the 1990s. Nevertheless, the increase of the far-right agenda across Europe, together with difficult social conditions in Serbia, clearly points that renewed pervasive "nationalization“ of the political space is becoming potentially realistic. If the conditions are met, the beloved club can once again shine with its full national glow.

\section{REFERENCES}

Andjelić, Neven. 2014. The Rise and Fall of Yugoslavia: Politics and Football in the Service of Nation(s). Sudosteuropa no. 62 (2): 99-125

Brubaker, Rogers. 1996. Nationalism reframed: nationhood and the national question in the New Europe. Cambridge England ; New York: Cambridge University Press.

Čolović, Ivan. 2000. Politika simbola. Beograd: XX vek.

Čolović, Ivan. 2014. Rastanak sa identitetom. Beograd: XX vek.

Đerić, Gordana. 2007. O čemu govorimo kada čutimo i o čemu ćutimo kada govorimo? Filozofija i društvo no. $18(3): 43-57$.

Đerić, Gordana. 2008. Semantika ćutanja, nasilje i društveno pamćenje: intima hrvatske i srpske politike. Intima javnosti, ed. Gordana Đerić, 64-97. Beograd: Fabrika knjiga i Institut za filozofiju i društvenu teoriju.

Đorđević, Ivan. 2012. Twenty years later: The war did (not) begin at Maksimir an anthropological analysis of the media narratives about a never ended football game. Glasnik Etnografskog instituta SANU no. 60 (2)

Đorđević, Ivan. 2015a. Antropolog među navijačima. Beograd: XX vek. 
Đorđević, Ivan. 2015b. Između ponosa i srama. Antropološka analiza narativa o „Paradi ponosa“ u savremenoj Srbiji. Glasnik Etnografskog instituta SANU, no. 68 (2): 351-366.

Edelman, Robert. 2013. Football in the Era "Changing Stagnation". The Case of Spartak Moscow. Soviet society in the era of late socialism, 1964 - 1985, ed. Neringa Klumbyte and Gulnaz Sharafutdinova, vii, 251 pages. Lanham: Lexington Books.

Foer, Franklin. 2004. How soccer explains the world: an unlikely theory of globalization. New York: HarperCollins.

Goldblatt, David. 2008. The ball is round : a global history of football. 1st Riverhead trade pbk. ed. New York: Riverhead Books.

Jansen, Stef. 2005. Antinacionalizam. Beograd: XX vek.

Kuper, Sajmon. 2007. Fudbalom protiv neprijatelja. Beograd: Samizdat B92.

Lalić, Dražen. 1990. Nasilništvo nogomentnih navijača. Geneza fenomena u Jugoslaviji. Kultura no. 88-90.

Mihailović, Srećko. 1997. Rat je počeo 13. maja 1990. Rat je počeo na Maksimiru, ed. Svetlana Slapšak and Hari Štajner, 77-124. Beograd: Medija centar.

Mikus, Marek. 2011. 'State Pride": Politics of LGBT Rights and Democratisation in 'European Serbia". East European Politics and Societies no. 25 (4):834-851.

Mills, Richard. 2009. 'It All Ended in an Unsporting Way': Serbian Football and the Disintegration of Yugoslavia, 1989-2006. International Journal of the History of Sport no. 26 (9):1187-1217.

Nielsen, Christian Axboe. 2010. The goalposts of transition: football as a metaphor for Serbia's long journey to the rule of law. Nationalities Papers no. 38 (1):87-103.

Nielsen, Christian Axboe. 2013. Stronger than the state? Football hooliganism, political extremism and the Gay Pride Parades in Serbia. Sport in Society no. 16 (8).

Riordan, James. 1999. The impact of communism on sport. The international politics of sport in the 20th century, ed. James Riordan and Arnd Kruger, London, New York: E \& FN Spon ; Routledge.

Sack, Allen, and Zeljan Suster. 2000. Soccer and Croatian Nationalism. A Prelude to War. Journal of Sport \& Social Issues no. 24 (3):305-320.

Spasić, Ivana. 2003. Sećanje na nedavnu prošlost. Politika i svakodnevni život. Srbija 1999-2002, ed. Zagorka Golubović, Ivana Spasić and Đorđe Pavićević. Beograd: Institut za filozofiju i društvenu teoriju.

Tompson, Mark. 2000. Proizvodnja rata: Mediji u Srbiji, Hrvatskoj i Bosni i Hercegovini. Beograd: Medija centar Beograd i Free B92.

Vasiljević, Jelena. 2008. Procesi narativizacije srpsko - hrvatskih sukoba u stampi Hrvatske i Srbije prve polovine devedesetih godina XX veka, MPhil Thesis, Filozofski fakultet, Odeljenje za etnologiju i antropologiju, Beograd, Beograd.

Vasiljević, Jelena. 2011. Ključni elementi transformacije režima državljanstva u Srbiji od 1990. godine. Filozofija i društvo no. XXII (4):63-82.

Velikonja, Mitja. 2009. Povratak otpisanih. Emancipatorski potencijali jugonostalgije. Zid je mrtav, živeli zidovi!, ed. Ivan Čolović. Beograd: XX vek.

Vrcan, Srđan, and Dražen Lalić. 1999. From Ends to Trenches and Back: Football in the Former Yugoslavia. Football Cultures and Identities, ed. Gary Armstrong and Richard Giulianotti. Basingstoke: Macmillan.

Vrcan, Srđan. 2003. Nogomet-politika-nasilje: ogledi izsociologije nogometa. Zagreb: Naklada Jesenski i Turk.

Wilson, Jonathan. 2006. Behind the Curtain: Football in Eastern Europe: Travels in Eastern European Football. London: Orion. 
Zec, Dejan. 2010. The Origin of Soccer in Serbia. Serbian Studies: Journal of the North American Society for Serbian Studies no. 24 (1-2):137-59.

Zec, Dejan. 2011. Oaza normalnosti ili tužna slika stvarnosti? Fudbal u okupiranoj Srbiji (1941-1944). Godišnjak za društvenu istoriju XVIII (3): 49-70.

Žikić, Bojan. 2012. Misao, kultura, identitet. Beograd: Srpski genealoški centar.

\section{VLOGA NOGOMETNEGA KLUBA CRVENA ZVEZDA PRI OBLIKOVANJU SRBSKE NACIONALNE IDENTITETE}

Glavni namen prispevka je pregled in analiza socialnih, političnih in zgodovinskih procesov, zaradi katerih je v specifičnih okolisčinah beograjski nogometni klub Crvena zvezda zaslovel kot »klub - heroj«. Kot pravi avtor, so se v tem klubu ohranile različne "vrednote iz preteklosti, zaradi katerih se je nogometna ekipa ob nastajanju in oblikovanju nove države labko vzpostavila kot nacionalni simbol. S povezovanjem različnih virov prispevek prikaže, kako se je nogometna reprezentanca preoblikovala od lokalne do nacionalne "blagovne znamke«, pri čemer posebej izpostavi vlogo nogometa $v \grave{c} a s u, k o$ je razpadala Jugoslavija, in se osredotoči na motive za preoblikovanje Crvene zvezde v simbolni "steber srbstva". Kljub nižji kakovosti nogometa po tranziciji leta 2000 se politična vloga nogometnega kluba ni zmanjšala, ravno tako pa ni upadel navijaški zanos. Zvesti navijači ostajajo "psi čuvaji patriotskih vrednot, in to tudi v času demokratizacije in liberalizacije srbske družbe, Crvena zvezda pa tudi v sodobnem času ostaja osrednji nacionalni simbol.

Dr. Ivan Đorđević, Institute of Ethnography, Serbian Academy of Sciences and Arts, Knez Mihajlova 36, 11000 Belgrade, Serbia, scedo@eunet.rs 